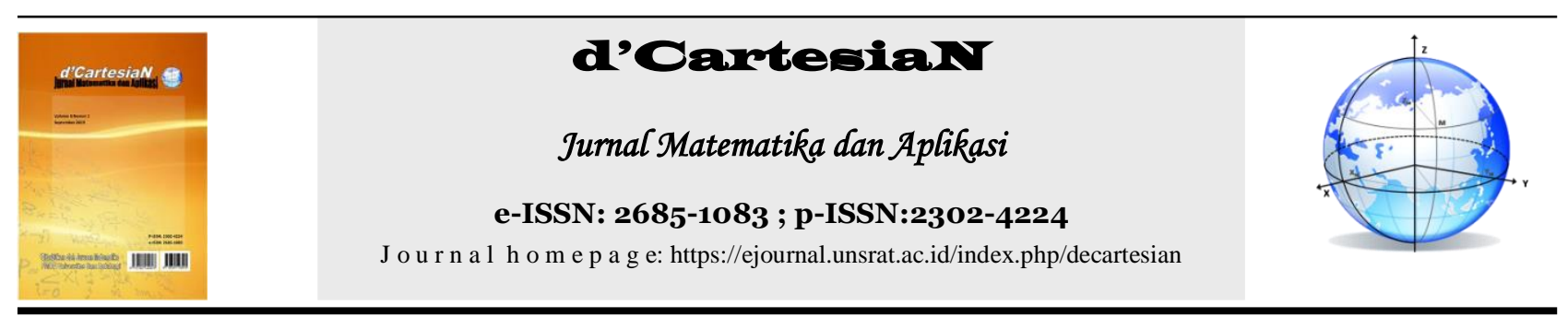

\title{
Hubungan Cuaca dan Tanaman Pangan Menggunakan Regresi Linear di Kota Tondano
}

\author{
Maharani Mananohas ${ }^{1}$, Maria D. Bobanto' Ferdy $^{1^{*}}$ \\ ${ }^{1}$ Jurusan Fisika-Fakultas Matematika dan Ilmu Pengetahuan Alam-Universitas Sam Ratulangi Manado, Indonesia \\ ${ }^{*}$ Corressponding author : fsagita@gmail.com
}

\begin{abstract}
A B S T R A K
Penelitian ini bertujuan untuk mengetahui hubungan antara cuaca (curah hujan dan intensitas matahari) terhadap tanaman pangan (padi sawah, jagung dan kacang tanah). Hasilnya menunjukkan Pengaruh terhadap produktifitas tanaman pangan padi di Kota Tondano adalah curah hujan terhadap padi $8 \%$ dan Intensitas matahari terhadap padi $3,8 \%$. Untuk curah hujan terhadap jagung $12,2 \%$ dan intensitas matahari terhadap jagung 33.6\%. Untuk curah hujan terhadap kacang tanah $43,4 \%$ dan intensitas matahari terhadap kacang tanah 99,2\%.
\end{abstract}

\section{ABSTRACT}

Thia research purpose was to know the relation between weather (rainfall and sun intensity) and crops (rice, corn , and peanut). The results showed that, rainfall effect on rice at Tondano City was $8 \%$ and sun intensity effect on rice was $3.8 \%$. For rainfall effect on corn was $12.2 \%$ and sun intensity was $33.6 \%$. For rainfall effect on peanuts was $43.4 \%$ and sun intensity was $99.2 \%$.

\section{INFO ARTIKEL}

Diterima : 18 Juli 2019

Diterima setelah revisi : 24 Juli 2019

Tersedia online : 25 Juli 2019

\section{Kata Kunci:}

Cuaca

Tanaman Pangan

Regresi Linear

\section{ARTICLE INFO}

Accepted : 18 July 2019

Accepted after revision : 24 July 2019

Available online : 25 Julv 2010

\author{
Keywords: \\ Weather \\ Crops \\ Linear Regression
}

\section{PENDAHULUAN}

Indonesia merupakan negara pertanian dimana pertanian memegang peranan penting dari keseluruhan perekonomian nasional. Hal ini dapat ditunjukkan dari banyaknya penduduk atau tenaga kerja yang hidup atau bekerja pada sektor pertanian dan produk nasional yang berasal dari pertanian. Sektor pertanian sangat rentan terhadap perubahan iklim karena berpengaruh terhadap pola tanam, waktu tanam, produksi, dan kualitas hasil [1].

Perubahan kondisi iklim bumi secara global akibat efek gas rumah kaca telah memberi dampak pada kondisi cuaca/ iklim ekstrim regional dan local wilayah Indonesia. Dampak kondisi penyimpangan iklim (cuaca ekstrim) yang nyatanya adalah meningkatnya intensitas curah hujan, banjir bandang dan banjir pasang, badai lokal, suhu perkotaan naik, kekeringan dan tanah longsor.

Dalam skala waktu perubahan iklim akan membentuk pola atau siklus tertentu, baik harian, musiman, tahunan maupun siklus beberapa tahunan. Selain perubahan yang berpola siklus, aktivitas manusia menyebabkan pola iklim berubah secara berkelanjutan, baik dalam skala global maupun skala lokal. Unsur-unsur iklim yang menunjukan pola keragaman yang jelas merupakan dasar dalam melakukan klasifikasi iklim. Unsur iklim yang sering dipakai adalah suhu dan curah hujan (presipitasi) Klasifikasi iklim umumnya sangat spesifik yang didasarkan atas tujuan penggunaannya, misalnya untuk pertanian, penerbangan atau kelautan. Pengklasifikasian iklim yang spesifik tetap menggunakan data unsur iklim sebagai landasannya, tetapi hanya memilih data unsur-unsur iklim yang berhubungan dan secara langsung mempengaruhi aktivitas atau objek dalam bidang-bidang tersebut [2].

Dengan demikian data meteorologi sangat penting dalam bidang agrokultur, sejak dulu kegiatan pertanian bergantung pada cuaca. Banyak manfaat yang dapat kita peroleh dari data meteorologi. Salah satu contohnya dalam penelitian ini yaitu aplikasi meteorologi pada produksi tanaman pangan. Dimana tanaman pangan berperan penting bagi perekonomian Indonesia.

Penelitian ini mengarah kepada hubungan iklim lokal terhadap produktivitas tanaman pangan (padi, jagung dan kacang tanah) di Kota Tondano. Wilayah Kota Tondano ini sebagian besar memiliki lahan pertanian yang cukup luas dan memiliki sumber air yang memadai maka dari itu penelitian lakukan di Kota Tondano. Penelitian dilakukan dengan menggunakan metode analisis statistik regresi linear sederhana. 


\subsection{Iklim dan Tanaman}

Iklim adalah salah satu faktor yang mempengaruhi pertumbuhan dan produktivitas tanaman. Sektor pertanian merupakan salah satu sektor penggerak perekonomian yang berisiko akibat adanya perubahan iklim. Beberapa kategori perubahan iklim yang dapat menurunkan produksi hasil pertanian seperti suhu ekstrim, gelombang panas, kekeringan, badai, hujan hingga mengakibatkan banjir. Berdasarkan gambaran iklim akan dapat diidentifikasi tipe vegetasi yang tumbuh dilokasi tersebut. Pada kondisi tertentu pengaruh iklim terhadap vegetasi yang tumbuh di suatu tempat yang jauh lebih kuat dibandingkan dengan pengaruh tanah. Hal ini dapat dilihat pada tanah yang sama ternyata vegetasi penutupnya jauh berbeda akibat kondisi iklim yang berbeda. Untuk mengetahui apakah tanaman atau makhluk hidup lainnya dapat hidup sesuai pada iklim tertentu, diperlukan informasi iklim yang lebih rinci dari beberapa dekade dengan nilai rata-rata bulan dengan pola sebarannya sepanjang tahun. Sedangkan untuk menduga keragaman tanaman, diperlukan informasi harian [3].

Pengaruh unsur-unsur iklim lingkungan terhadap tanaman adalah menjadi penting dengan semakin besarnya tanaman dan semakin banyaknya jumlah rumpun tanaman. Pada awalnya tanaman hanya dipengaruhi oleh iklim mikro saja, namun kemudian dipengaruhi oleh meso dan iklim makro. Ada hubungan erat antara pola iklim dengan distribusi tanaman sehingga beberapa klasifikasi iklim didasarkan pada dunia tumbuh - tumbuhan. Tanaman dipandang sebagai suatu yang kompleks dan peka terhadap pengaruh iklim misalnya pemanasan, kelembaban, penyinaran matahari, dan lain-lain [4].

\subsubsection{Tanaman Pangan}

Pangan diartikan sebagai segala sesuatu yang bersumber dari sumber hayati dan air, baik yang diolah maupun tidak diolah.

1. Padi

Tanaman padi (Oryza sativa L.) merupakan tanaman pangan penting yang telah menjadi makanan pokok lebih dari setengah penduduk dunia. Di Indonesia, padi merupakan komoditas utama dalam menyokong pangan masyarakat. Indonesia sebagai negara dengan jumlah penduduk yang besar menghadapi tantangan dalam memenuhi kebutuhan pangan penduduk. Oleh karena itu, kebijakan ketahanan pangan menjadi fokus ut ama dalam pembangunan pertanian. Konsumsi beras pada tahun 2011 mencapai 139 kg kapita-1 tahun-1 dengan jumlah penduduk 237 juta jiwa, sehingga konsumsi beras nasional pada tahun 2011 mencapai 34 juta ton. Kebutuhan akan beras terus meningkat seiring dengan laju pertumbuhan penduduk yang lebih cepat dari pertumbuhan produksi pangan yang tersedia [5].

2. Jagung

Jagung (Zea mays L.) merupakan salah satu bahan pangan yang penting di Indonesia karena jagung merupakan sumber karbohidrat kedua setelah beras. Di samping itu, jagung juga merupakan bahan baku industri dan pakan ternak. Kebutuhan jagung di Indonesia untuk konsumsi meningkat sekitar $5,16 \%$ per tahun sedangkan untuk kebutuhan pakan ternak dan bahan baku industri naik sekitar 10,87\% per tahun [6].

3. Kacang Tanah

Kacang tanah (Arachis hypogeae L.) merupakan tanaman pangan ke dua terpenting setelah kedelai. Sebagai bahan pangan dan pakan ternak yang bergizi tinggi, kacang tanah mengandung lemak (40,50\%), protein (27\%), karbohidrat serta vitamin (A, B, C, D, E dan $\mathrm{K}$ ), juga mengandung mineral antara lain Calcium, Chlorida, Ferro, Magnesium, Phospor, Kalium dan Sulphur. Lima manfaat kacang tanah untuk kesehatan : 1) Kacang tanah dikenal sebagai lemak baik yang menurunkan resiko penyakit jantung dengan cara menurunkan kolesterol jahat (LDL) dalam tubuh, 2) Kandungan resveratrol, bermanfaat bagi kelancaran fungsi tubuh, 3) Mengandung folat niasin, mangan, protein, serta vitamin E yang melimpah, sangat baik untuk kelancaran fungsi usus, 4) Mengandung serat, membantu menurunkan resiko kanker usus besar dan pembentukan batu empedu, 5) Mengandung limpahan kalsium dan vitamin D, yang dapat membantu menjaga kesehatan tulang dan gigi. Dan dalam jangka panjang mencegah serangan osteoporosis. Melihat pentingnya peranan kacang tanah bagi manusia, maka teknik budidaya kacang tanah perlu diperhatikan [7].

\subsubsection{Curah Hujan}

Curah hujan adalah butir-butir air atau kristal es yang jatuh/ keluar dari awan atau kelompok awan. Jika curahan dimaksud dapat mencapai permukaan bumi disebut sebagai hujan. Jika setelah keluar dari dasar awan tetapi tidak jatuh sampai ke permukaan bumi disebut sebagai virga.

Banyaknya curah hujan yang mencapai permukaan bumi atau tanah selama selang waktu tertentu dapat diukur dengan jalan mengukur tinggi air hujan dengan cara tertentu. Hasil dari pengukurannya dinamakan curah hujan, yaitu tanpa mengingat macam atau bentuknya pada saat mencapai permukaan bumi dan tidak memperhitungkan endapan yang meresap ke dalam tanah, hilang karena penguapan, atau pun mengalir.

Terjadinya iklim ekstrim berdampak cukup besar terhadap tanaman semusim, terutama tanaman pangan. Salah satu unsur iklim yang dapat digunakan sebagai indikator dalam kaitannya dengan tanaman adalah curah hujan. Mengingat curah hujan merupakan unsur iklim yang fluktuasinya tinggi dan pengaruhnya terhadap produksi tanaman cukup signifikan. Jumlah curah hujan secara keseluruhan sangat penting dalam menentukan hasil [8].

\subsubsection{Intensitas Matahari}

Matahari merupakan kendali cuaca serta iklim yang sangat penting dan sebagai sumber energi tama di bumi yang menggerakkan udara dan arus laut. Energi matahari diradiasikan ke segala arah, sebagian hilang ke alam semesta, dan hanya sebagian kecil saja yang dapat diterima bumi [9]. Bumi berevolusi mengelilingi matahari pada jarak rata-rata 93 juta mil. Orbit bumi berbentuk elips dengan eksentrisitas sangat kecil (o,017), ini berarti orbit bumi hampir berbentuk lingkaran. Jarak matahari-bumi yang terdekat disebut perihelion, terjadi pada tanggal 4 Januari dengan jarak 91,5 juta mil, dan jarak matahari-bumi yang terjauh 
disebut aphelion terjadi pada tanggal 5 Juli dengan jarak 94,5 juta mil [10].

Radiasi adalah suatu bentuk energi yang dipancarkan oleh setiap benda yang mempunyai suhu di atas nol mutlak dan merupakan satu-satunya bentuk energi yang dapat menjalar di dalam vakum angkasa luar. Radiasi matahari merupakan gelombang elektromagnetik yang terdiri atas medan listrik dan medan magnet. Matahari setiap menit memancarkan energi sebesar 56x1026 kalori. Dari energi ini bumi menerima 2,55x1018 kalori atau hanya $1 / 2 \times 109 n y a$ [11].

Cahaya matahari merupakan sumber utama energi bagi kehidupan, tanpa adanya cahaya matahari kehidupan tidak akan ada. Bagi pertumbuhan tanaman ternyata pengaruh cahaya selain ditentukan oleh kualitasnya ternyata ditentukan intensitasnya. Intensitas cahaya adalah banyaknya energi yang diterima oleh suatu tanaman per satuan luas dan per satuan waktu (kal/cm2/hari). Dengan demikian pengertian intensitas yang dimaksud sudah termasuk lama penyinaran, yaitu lama matahari bersinar dalam satu hari. Pada dasarnya intensitas cahaya matahari akan berpengaruh nyata terhadap sifat morfologi tanaman. Hal ini dikarenakan intensitas cahaya matahari dibutuhkan untuk berlangsungnya penyatuan $\mathrm{CO} 2$ dan air untuk membentuk karbohidrat. Berdasarkan ekologi terhadap kemampuan penerimaan cahaya, Lukitasari [12] menyatakan bahwa secara garis besar tanaman dapat dibedakan menjadi dua tipe, yaitu: 1) Heliofit, tanaman yang tumbuh baik jika terkena cahaya matahari penuh, dan 2) Skiofit, tanaman yang tumbuh baik pada intensitas cahaya yang rendah. Terdapat dua faktor yang mempengaruhi pertumbuhan tanaman, yaitu faktor makro dan faktor mikro. Yang termasuk dalam faktor makro adalah: cahaya matahari, suhu, kelembaban, awan, angin, serta pencemaran udara. Sedangkan faktor mikro meliputi media tumbuh dan kandungan $\mathrm{O} 2$ dan $\mathrm{CO} 2$ yang ada di udara, tanaman yang mendapatkan cahaya matahari dengan intensitas yang tinggi menyebabkan lilit batang tumbuh lebih cepat, susunan pembuluh kayu lebih sempurna, internodia menjadi lebih pendek, daun lebih tebal tetapi ukurannya lebih kecil dibanding dengan tanaman yang terlindung. Beberapa efek dari cahaya matahari penuh yang melebihi kebutuhan optimum akan dapat menyebabkan layu, fotosistesi lambat, laju respirasi meningkat tetapi kondisi tersebut cenderung mempertinggi daya tahan tanaman.

\subsection{Statistika}

Statistika sebagai pengetahuan yang berhubungan dengan cara-cara pengumpulan fakta, pengolahan serta pembuatan keputusan yang cukup beralasan berdasarkan fakta dan analisa yang dilakukan. Sementara statistik dipakai untuk menyatakan kumpulan fakta, umumnya berbentuk angka yang disusun dalam tabel atau diagram yang melukiskan atau menggambarkan suatu persoalan. Analisis regresi merupakan salah satu teknik analisis data dalam statistika yang seringkali digunakan untuk mengkaji hubungan antara beberapa variabel dan meramal suatu variable. Dalam mengkaji hubungan antara beberapa variabel menggunakan analisis regresi, terlebih dahulu peneliti menentukan satu variabel yang disebut dengan variabel tidak bebas dan satu atau lebih variabel bebas. Jika ingin dikaji hubungan atau pengaruh satu variabel bebas terhadap variabel tidak bebas, maka model regresi yang digunakan adalah model regresi linier sederhana. Kemudian Jika ingin dikaji hubungan atau pengaruh dua atau lebih variabel bebas terhadap variabel tidak bebas, maka model regresi yang digunakan adalah model regresi linier berganda (multiple linear regression model). Kemudian untuk mendapatkan model regresi linier sederhana maupun model regresi linier berganda dapat diperoleh dengan melakukan estimasi terhadap parameter-parameternya menggunakan metode tertentu.

\subsection{Regresi Linear}

Istilah regresi pertama kali digunakan dalam statistik oleh Sir Francis Galton pada tahun 1877. Galton melakukan penelitian yang menunjukkan bahwa sifat tinggi badan anak yang dilahirkan ternyata menurun (regress) dari tinggi badan orang tuanya. Kemudian Galton menggunakan kata "regresi" untuk menamakan analisis proses prediksi keterkaitan antara variabel tinggi badan anak dengan tinggi badan orang tuanya. Perkembangan selanjutnya para peneliti menggunakan istilah multiple regression atau regresi berganda

\subsection{Korelasi}

Korelasi merupakan istilah yang digunakan untuk mengukur kekuatan hubungan antarvariabel. Analisis korelasi adalah cara untuk mengetahui ada atau tidak adanya hubungan antarvariabel. Kekuatan hubungan antar variabel dapat dilihat dari hasil nilai koefisien korelasi. Koefisien korelasi (KK) merupakan indeks atau bilangan yang digunakan untuk mengukur keeratan (kuat, lemah, atau tidak ada) hubungan antarvariabel. Koefisien korelasi ini memiliki nilai antara -1 dan $+1(-1 \leq \mathrm{KK} \leq+1)$, dengan arti yaitu:

1. Jika KK bernilai positif, maka variabelvariabel berkorelasi positif. Semakin dekat nilai $\mathrm{KK}$ ini ke +1 semakin kuat korelasinya, demikian pula sebaliknya.

2. Jika KK bernilai negatif, maka variabelvariabel berkorelasi negatif. Semakin dekat nilai KK ini ke -1 semakin kuat korelasinya, demikian pula sebaliknya.

3. Jika KK bernilai o (nol), maka variabel variabel tidak menunjukkan korelasi.

4. Jika KK bernilai +1 atau -1 , maka variabel menunjukkan korelasi positif atau negatif yang sempurna.

Keeratan hubungan atau korelasi antarvariabel diberikan nilai - nilai dari KK sebagai patokan. Berikut ini adalah patokan dari nilai KK tersebut.

1. $\mathrm{KK}=\mathrm{O}$, tidak ada korelasi.

2. $\mathrm{O}<\mathrm{KK} \leq 0,20$, korelasi sangat rendah atau lemah sekali.

3. $0,20<\mathrm{KK} \leq 0,40$, korelasi rendah atau lemah tapi pasti.

4. $0,40<\mathrm{KK} \leq 0,70$, korelasi yang cukup berarti.

5. $\quad 0,70<\mathrm{KK} \leq 0,90$, korelasi yang tinggi; kuat.

6. $0,90<\mathrm{KK}<1,00$, korelasi sangat tinggi; kuat sekali; dapat diandalkan.

7. $\mathrm{KK}=1$, korelasi sempurna. [14]

Korelasi digunakan untuk mengetahui hubungan di antara dua variabel, dan jika ada hubungan bagaimana arah hubungan tersebut. Keeratan hubungan antara satu variabledengan variable yang lain biasa disebut dengan Koefisien Korelasi yangditandai dengan "r". Adapun rumus "r" adalah :

$$
r=\frac{N\left(\sum \mathrm{xy}\right)-\left(\sum \mathrm{x}\right)\left(\sum \mathrm{y}\right)}{\left\{\left(N \sum x^{2}-\left(N \sum y^{2}-\left(\sum \mathrm{y}\right)^{2}\right)\right\}\right.}
$$

Dimana : 
$\mathrm{r}=$ nilai koefisien korelasi

$\mathrm{x}=$ nilai variabel pertama

$\mathrm{y}=$ nilai variabel kedua

$\mathrm{N}=$ Jumlah data [13]

\subsection{Koefisien Determinasi}

Koefisien determinasi $\left(\mathrm{R}^{2}\right)$ pada intinya mengukur seberapa jauh kemampuan model dalam menerangkan variasi variabel terikat. Nilai koefisien determinasi adalah diantara nol dan satu. Nilai $\mathrm{r}^{2}$ yang celi berarti kemampuan variabel-variabel independen dalam menjelaskan variasi variabel dependen amat terbatas. Nilai yang mendekati satu berarti variabel-variabel independen memberikan hampir semua informasi yang dibutuhkan untuk memprediksi variasi variabel dependen [15]

$$
r^{2}=\frac{\left(\boldsymbol{N}\left(\sum \mathrm{xy}\right)-\left(\sum \mathrm{x}\right)\left(\sum \mathrm{y}\right)\right)^{2}}{\left(\boldsymbol{N} \sum x^{2}-\left(N \sum y^{2}-\left(\sum \mathrm{y}\right)^{2}\right)^{2}\right.}
$$

\section{METODE PENELITIAN}

\subsection{Waktu dan Tempat Penelitian}

Penelitian ini dilaksanakan di wilayah Kota Tondano mulai dari bulan November sampai bulan Januari. Metode dasar yang digunakan dalam penelitian ini adalah Metode Regresi Linear.

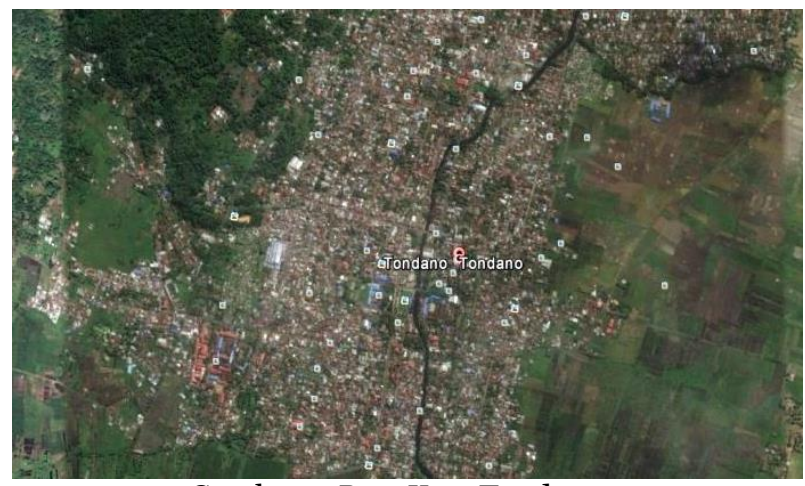

Gambar 1. Peta Kota Tondano.

\subsection{Metode Regresi Linear}

Regresi digunakan untuk mengukur hubungan dua variabel atau lebih yang dinyatakan dengan bentuk hubungan atau fungsi. Regresi linier ialah bentuk hubungan di mana variabel bebas $\mathrm{X}$ maupun variabel tergantung Y sebagai faktor yang berpangkat satu. Regresi linier yang digunakan adalah regresi linier sederhana dengan bentuk fungsi:

$$
Y=a+b X
$$

\subsection{Data Penelitian}

1. Data Curah Hujan dan Intensitas Matahri Data bulanan kota Tondano meliputi curah hujan dan intensitas matahari tahun 2008 2012 , pada Badan Meteorologi Klimatologi dan Geofisika (BMKG) Tondano.

2. Data Produktivitas Tanaman Pangan Data tahunan hasil produktivitas tanaman pangan Kota Tondano meliputi padi, jagung dan kedelai tahun 2009 - 2012, pada Badan Pusat Statistik (BPS) Kota Tondano.

\subsection{Prosedur}

Pengumpulan data sekunder dikumpulkan dari dinas Badan Pusat Statistika Kota Tondano mulai tahun 2009 hingga 2012, dan BMKG Kota Tondano diantaranya adalah Curah Hujan dan Intensitas Matahari dari tahun 2008 hingga 2012. Dan untuk melihat pengaruh iklim terhadap hasil produktivitas tanaman pangan meliputi padi, jagung dan kacang tanah, pengujian ini dilakukan pada Microsoft excel, dimana data tanaman pangan dan iklim sebagai input dan output.

\subsection{Diagram Alir Penelitian}

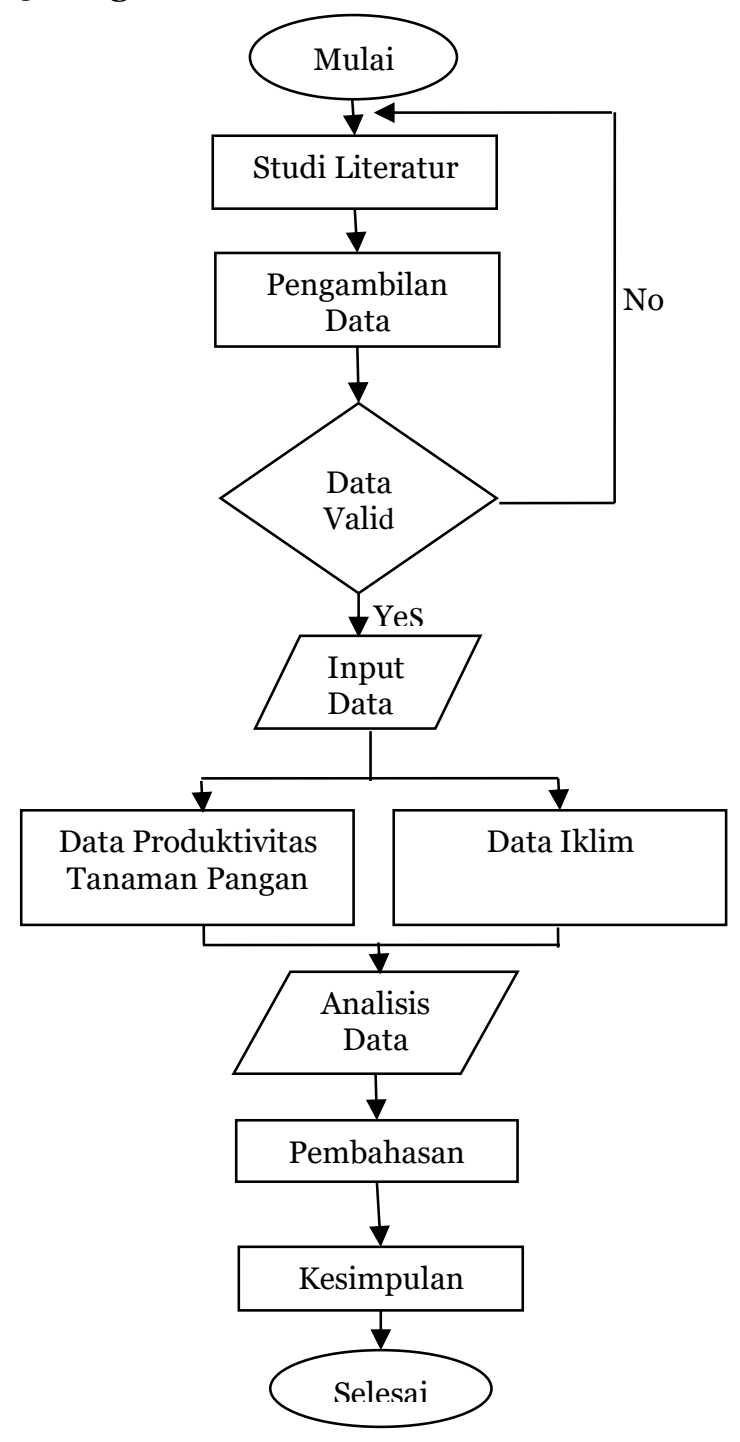

Gambar 2. Diagram alir penelitian.

\section{HASIL DAN PEMBAHASAN}

\subsection{Hubungan Curah Hujan terhadap Padi} Sawah

Gambar 3 hubungan curah hujan terhadap padi sawah mempunyai hubungan positif. Nilai koefisien korelasi (r) diperoleh sebesar 0,29 dilihat dari nilai korelasi hubungan variabel tersebut termasuk kategori rendah atau lemah tapi pasti. 


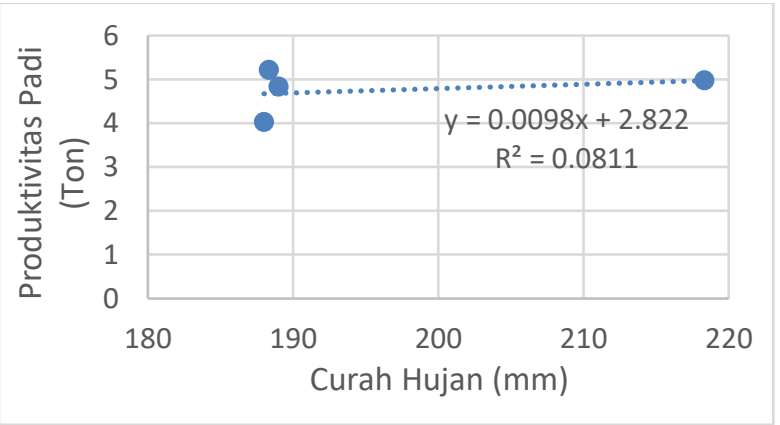

Gambar 3. Grafik hubungan curah hujan terhadap padi.

Nilai koefisien determinasi $\left(\mathrm{R}^{2}\right)$ diperoleh sebesar o,o8 hal ini menunjukan bahwa kemampuan curah hujan dalam memengaruhi produksi padi sawah di kota Tondano sebesar $8 \%$ sisanya dipengaruhi oleh faktor lain.

\subsection{Hubungan Intensitas Matahari terhadap Padi Sawah}

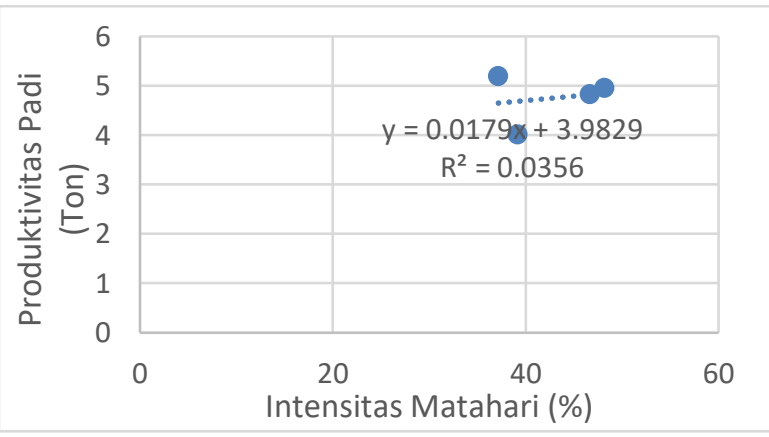

Gambar 4. Grafik hubungan intensitas matahari terhadap padi.

Gambar 4 hubungan intensitas matahari terhadap padi sawah mempunyai hubungan positif. Nilai koefisien korelasi (r) diperoleh sebesar 0,195 dari nilai korelasi hubungan variabel tersebut termasuk kategori rendah atau lemah sekali.

Nilai koefisien determinasi $\left(\mathrm{R}^{2}\right)$ diperoleh sebesar o,035 hal ini menunjukan bahwa kemampuan curah hujan dalam memengaruhi produksi padi sawah di kota Tondano sebesar $3,5 \%$ sisanya dipengaruhi oleh faktor lain.

\subsection{Hubungan Curah Hujan dan Jagung}

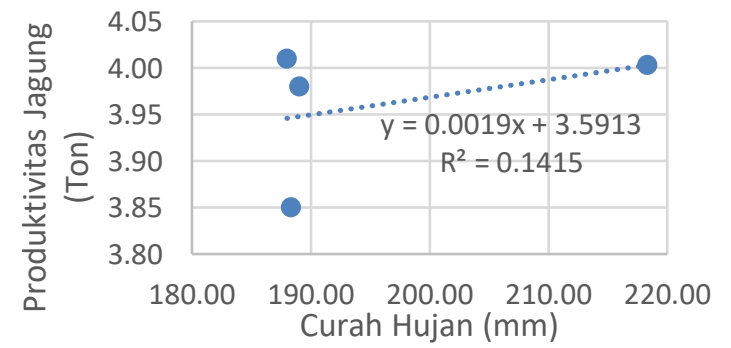

Gambar 5. Grafik hubungan curah hujan dan jagung.
Gambar 5 hubungan curah hujan terhadap jagung mempunyai hubungan positif. Nilai koefisien korelasi (r) diperoleh sebesar 0,350 dari nilai korelasi hubungan variabel tersebut termasuk kategori rendah atau lemah tapi pasti.

Nilai koefisien determinasi $\left(\mathrm{R}^{2}\right)$ diperoleh sebesar o,14 hal ini menunjukan bahwa kemampuan curah hujan dalam memengaruhi produksi jagung di kota Tondano sebesar 14\% sisanya dipengaruhi oleh faktor lain.

\subsection{Hubungan Intensitas Matahari dan Jagung}

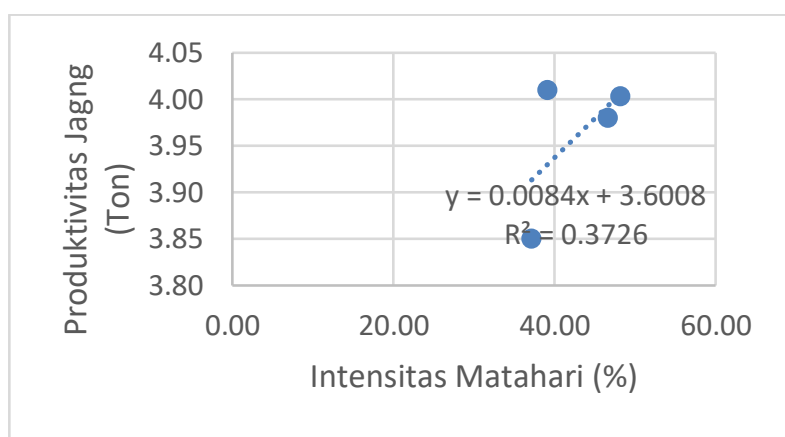

Gambar 6. Grafik hubungan intensitas matahari dan jagung.

Gambar 6 hubungan intensitas matahari terhadap jagung mempunyai hubungan positif. Nilai koefisien korelasi (r) diperoleh sebesar o,580 dari nilai korelasi hubungan variabel tersebut termasuk kategori yang cukup.

Nilai koefisien determinasi $\left(\mathrm{R}^{2}\right)$ diperoleh sebesar 0,37 hal ini menunjukan bahwa kemampuan intensitas matahari dalam memengaruhi produksi jagung di kota Tondano sebesar $37 \%$ sisanya dipengaruhi oleh faktor lain.

\subsection{Hubungan Curah Hujan dan Kacang Tanah}

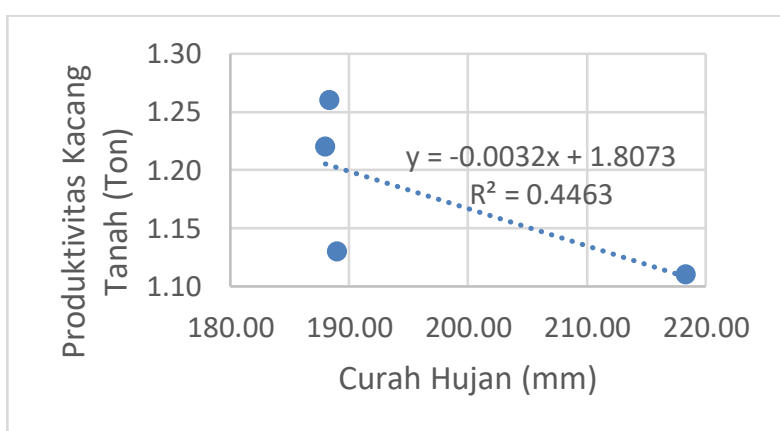

Gambar 7. Grafik hubungan curah hujan dan kacang tanah.

Gambar 7 hubungan curah hujan terhadap kacang tanah mempunyai hubungan negatif. Nilai koefisien korelasi (r) diperoleh sebesar o,66 dari nilai korelasi hubungan variabel tersebut termasuk kategori yang cukup.

Nilai koefisien determinasi $\left(\mathrm{R}^{2}\right)$ diperoleh sebesar o,446 hal ini menunjukan bahwa kemampuan curah hujan dalam memengaruhi produksi kacang tanah di kota Tondano sebesar 44,6\% sisanya dipengaruhi oleh faktor lain. 


\subsection{Hubungan Intensitas Matahari dan Kacang Tanah}

Gambar 8 hubungan intensitas matahari terhadap kacang tanah mempunyai hubungan negatif. Nilai koefisien korelasi (r) diperoleh sebesar 0,996 dari nilai korelasi hubungan variabel tersebut termasuk kategori yang sangat kuat.

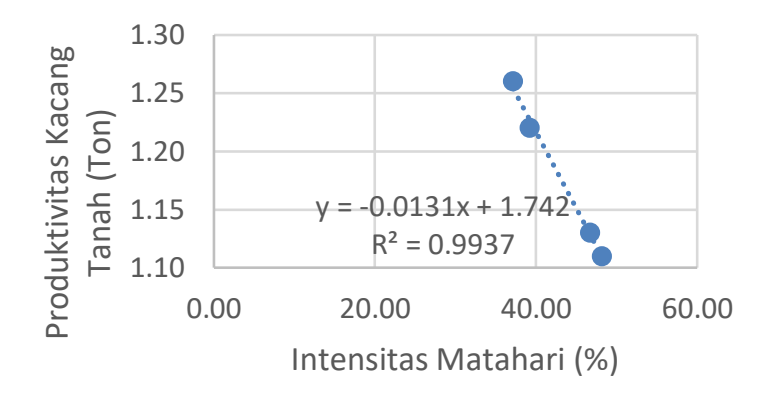

Gambar 8. Grafik hubungan intensitas matahari dan kacang tanah.

Nilai koefisien determinasi $\left(\mathrm{R}^{2}\right)$ diperoleh sebesar 0.993 hal ini menunjukan bahwa kemampuan intensitas matahari dalam memengaruhi produksi kacang tanah di kota Tondano sebesar 99,3\% sisanya dipengaruhi oleh faktor lain.

\section{PENUTUP}

\subsection{Kesimpulan}

Hubungan curah hujan terhadap padi sawah dan jagung memiliki hubungan positif sedangkan hubungan curah hujan terhadap kacang tanah menunjukkan hubungan negatif dikarenakan wilayah Tondano memiliki pengairan yang berasal dari danau Tondano.

Pengaruh intensitas matahari terhadap padi sawah dan jagung memiliki hubungan yang positif sedangkan intensitas matahari dan kacang tanah menunjukkan hubungan negatif. Dan hasilnya menunjukkan pengaruh terhadap produktifitas tanaman pangan padi dikota Tondano adalah dengan mampu menerangkan variasi data 8\% curah hujan terhadap padi dan $3.5 \%$ intensitas matahari terahap padi. Untuk tanaman pangan jagung mampu menerangkan variasi data $14 \%$ curah hujan terhadap jagung dan $37 \%$ intensitas matahari terhadap jagung Untuk tanaman kacang tanah adalah mampu menerangkan variasi data $44.6 \%$ curah hujan terhadap kacang tanah dan $99.3 \%$ intensitas matahari terhadap kacang tanah.

\subsection{Saran}

Untuk mendapatkan hasil yang lebih akurat lagi peneliti lain harus memakai data lebih dari sepuluh (10) data dan untuk memakai metode ini disarankan untuk memikirkan kembali.

\section{REFERENSI}

[1] Nurdin. (2011). Antisipasi perubahan iklim untuk keberlanjutan ketahanan pangan. Sulawesi Utara: Universitas Negeri Gorontalo.

[2] Hidayati, Rini. (2001), Masalah Perubahan Iklim di Indonesia Beberapa Contoh Kasus, Bogor.
[3] Setiawan, E. (2009). Pemanfaatan Data Cuaca Untuk Pendugaan Produktivitas (Studi Kasus Tanaman Cabe Jamu Di Madura). Makalah disampaikan pada Lombah Karya Ilmiah Penerapan Metode Prakiraan Cuaca Jangka Pendek. BMG. Jakarta.

[4] Arini NA, Halide HH, Hasanah N. (2012). Prediksi Probabilitas Produktivitas Tanaman Pangan Di Kota Makasar Berbasis Iklim. Makasar: Universitas Hasanudin.

[5] Anggraini, Fita. (2013). Sistem Tanam dan Umur bibit pada tanaman Padi Sawah (Oryza sativaL.) Varietas Inpari 13. Malang : Universitas Brawijaya.

[6] Ekowati Diah dan Nasir Mochamad. (2011). Pertumbuhan Tanaman Jagung (Zea Mays L.) Varietas Bisi-2 Pada Pasir Reject dan Pasir Asli Di Pantai Trisik Kulonprogo. Yogyakarta : Universitas Gadjah Mada.

[7] Sondakh, Tommy D. (2012). Hasil Kacang Tanah (Arachys hypogaea L.) Pada Beberapa Jenis Pupuk Organik. Manado : Universitas Sam Ratulangi.

[8] Suciantini. (2015). Interaksi iklim (curah hujan) terhadap produksi tanaman pangan di Kabupaten Pacitan. ISSN: 2407-8050.

[9] Yuliatmaja, Mochamad Reza. (2009). Kajian Lama Penyinaran Matahari dan Intensitas Radiasi Matahari Terhadap Pergerakan Semu Matahari Saat Solstice Di Semarang. Semarang: Universitas Negeri Semarang.

[10] Tjasyono, Bayong. 2004. Klimatologi. Bandung : ITB.

[11] Prawirowardoyo, Susilo. (1996). Meteorologi. Bandung : ITB.

[12] Lukitasari. (2010). Pengaruh Intensitas Cahaya Matahari Terhadap Pertumbuhan Tanaman Kedelai (Glycine Max). Madium : Ikip Pgri

[13] Nurjannah. (2014). Korelasi. Depok : Gunadarma.

[14] Suparto. (2014). Analisis Korelasi VariabelVariabel yang mempengaruhi siswa dalam memilih perguruan tinggi. Jurnal IPTEK Vol 18 No.2.

[15] Jamaluddin M. (2016). Pengaruh Perencanaan Anggaran dan Evaluasi Anggaran Terhadap Kinerja Organisasi dengan Standar Biaya Sebagai Variabel Moderating Pada Pemerintahan Daerah Kabupasten Wajo. Makassar : UIN Alauddin. 
Hubungan Cuaca dan Tanaman Pangan Menggunakan Regresi Linear di Kota Tondano d'Cartesian : Jurnal Matematika dan Aplikasi, Vol. 8 No. 2 (September 2019): 169-175

Maharani Mananohas (ranialamanda.ra@gmail.com)

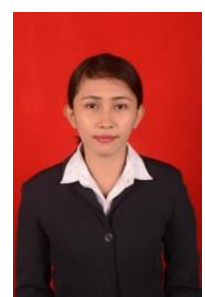

Lahir di Manado, Sulawesi Utara pada tanggal 13 Januari 1993. Menempuh pendidikan tinggi Jurusan Fisika, FMIPA, Universitas Sam Ratulangi Manado. Tahun 2018 adalah tahun terakhir ia menempuh studi. Makalah ini merupakan hasil penelitian skripsinya yang dipublikasikan

Maria D. Bobanto (lumiyohana5@gmail.com)

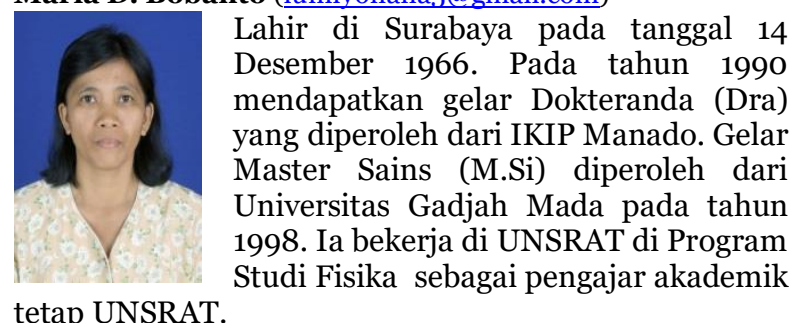

Ferdy (fsagita@gmail.com)

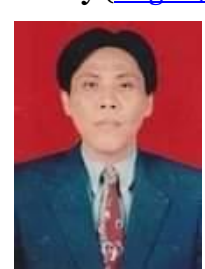

Lahir di Palu pada tanggal 19 Desember 1969. Pengajar tetap di Jurusan Fisika yang mendapat gelar Sarjana Sains (S.Si) di Universitas Hasanudin Makassar pada tahun 1996 dan gelar Master Sains (M.Si) di Universitas Indonesia pada tahun 2003. 